\title{
СТРУКТУРНО-ДИНАМІЧНИЙ АНАЛІЗ РИНКУ ПРАЦІ УКРАЇНИ: ВИКЛИКИ СЬОГОДЕННЯ
}

\section{STRUCTURAL AND DYNAMIC ANALYSIS OF THE LABOR MARKET OF UKRAINE: CHALLENGES OF MODERNITY}

\author{
Аксьонова Ірина Вікторівна \\ кандидат економічних наук, доцент, \\ Харківський національний економічний університет \\ імені Семена Кузнеця \\ ORCID: https://orcid.org/0000-0003-2605-0455
}

\author{
Aksonova Iryna \\ Simon Kuznets Kharkiv National University of Economics
}

\begin{abstract}
Стаття присвячена дослідженню тенденцій на ринку праці в сучасних умовах. Визначено, що в умовах глобалізації, демографічної кризи, реформування системи вищої освіти, поширення процесів діджиталізації фрормується нова модель ринку праці, яка заснована на мережево-цифрових технологіях. Разом 3 тим, на формування й розвиток сучасного ринку праці впливають фрактори, що викликані пандемією «COVID-19». Проаналізовано динамічні зміни на ринку праці в період пандемії, проведено їх порівняння 3 попередніми періодами за показниками безробіття, кількості вакансій та навантаження на одну вакансію. Здійснено порівняльний аналіз структурних змін на національному ринку праці та визначено найбільш затребувані сфрери, уподобання роботодавців та пошукувачів роботи у 2020 та 2021 роках. Окреслено сучасні тенденції на ринку праці та перспективний напрямок його розвитку.
\end{abstract}

Ключові слова: ринок праці, безробіття, вакансія, навантаження на одну вакансію, цифрова економіка, модель ринку праці, пандемія «COVID-19».

Статья посвящена исследованию тенденций на рынке труда в современных условиях. Определено, что в условиях глобализации, демографического кризиса, реформирования системы высшего образования, распространения процессов диджитализации фрормируется новая модель рынка труда, которая основана на цифровых технологиях. Вместе с тем, на формирование и развитие современного рынка труда влияют фракторы, вызванные пандемией «COVID-19». Проанализированы динамические изменения на рынке труда в период пандемии, проведено их сравнение с предыдущими периодами по показателям безработицы, количества вакансий и нагрузки на одну вакансию. Проведен сравнительный анализ структурных изменений на национальном рынке труда и определены наиболее востребованные сореры, предпочтения работодателей и соискателей работы в 2020 и 2021 годах. Определены современные тенденции на рынке труда и перспективное направление его развития.

Ключевые слова: рынок труда, безработица, вакансия, нагрузка на одну вакансию, цифровая экономика, модель рынка труда, пандемия «COVID-19».

The article is devoted to the study of trends in the development of the labor market in modern conditions. It has been determined that the modern labor market is developing in the context of globalization changes, demographic crisis, the spread of migration processes, the reform of the higher education system, the spread of digitalization processes in the socio-economic sphere. In addition, at the present stage of economic development, a new labor market model based on digital technologies is being formed. At the same time, the formation and development of the labor market in modern conditions is influenced by the factors caused by the COVID-19 pandemic, which significantly increased inequality in the labor market, halted employment growth and accelerated the development of the fourth industrial revolution towards digitalization. The development of the labor market based on digital technologies requires the modernization of labor relations between employers and employees, new competencies from specialists. Global trends in the labor market in the digital economy, associated with the restructuring of many sectors of the economy in the direction of automation, digitalization, strengthening the role of information technology, are aimed at restructuring the structure of the labor market as a whole. This article is aimed at determining the structural and dynamic changes in the labor market, taking into account modern socio-economic trends and pandemic factors. 
The article highlights the key indicators of the state and development of the labor market, emphasizes the assessment of supply and demand through the indicators of unemployment, the number of vacancies and the load per vacancy. The situation on the labor market in Ukraine during the pandemic is analyzed and compared with previous periods for the above indicators in terms of types of economic activity, professional groups, regions. The assessment of trends in structural changes in the national labor market through the most popular areas, the preferences of employers and job seekers in 2020 and 2021. It is concluded that the modern period of economic development requires a quick response to changes in needs on the part of the labor market, new ways to improve the quality of labor potential and its adaptation to changing conditions. The current trends in the labor market and the promising direction of its development have been determined.

Keywords: labor market, unemployment, vacancy, load per vacancy, digital economy, labor market model, COVID-19 pandemic.

Постановка проблеми. Будь-який ринок в загальному сенсі - це система економічних відносин між продавцями і покупцями товарів і послуг. В класифікаційній структурі ринків особливе місце займає ринок праці, який $€$ вершиною ринкових відносин, оскільки управління економікою представляє, перш за все, управління трудовою діяльністю. Ринок праці $€$ органічною складовою економіки будь-якої країни, оскільки виконує фрункції механізму розподілу і перерозподілу суспільної праці за окремими сорерами і галузями господарства, за критеріями есрективності праці і виробництва відповідно до структури суспільних потреб і фрорм власності, видів і форм зайнятості.

Ринок праці розглядається як у широкому, так і у вузькому плані. Ринок праці в широкому плані, є сукупністю, яка охоплює економічно активне населення і загальну потребу економіки в робочій силі. У вузькому значенні - це характеристика поточного стану трудових ресурсів країни, яка складається 3 пропозиції робочої сили, тобто контингенту безробітного населення, що шукає роботу, і попиту на робочу силу або неукомплектовані робочі місця, що відображають незадоволену частину загальної потреби економіки в кадрах [4].

Роботодавець представляє на ринку праці сторону, яка формує попит на робочу силу, наймані робітники і безробітні - сторони, що фрормують пропозицію робочої сили, а елементи інорраструктури сприяють взаємодії цих суб'єктів ринку. У сучасних умовах вирішення питань розвитку національної економіки, підвищення ефективності її фрункціонування тісно пов'язане з відтворенням робочої сили i, насамперед, із станом та тенденціями у сорері зайнятості. Питання розвитку ринку праці набувають особливої актуальності в умовах глобалізації, демографрічної кризи, поширення міграційних процесів, ресрормування системи вищої освіти, поширення процесів діджіталізації.
Аналіз останніх досліджень і публікацій. Майже всі сучасні дослідження фахівців проводяться з урахуванням впливу наслідків пандемії «COVID-19» на різні сорери [8; 11; 12]. Питанням фрункціонування ринку праці та оцінці тенденцій, які відбуваються на ньому, також присвячено праці багатьох науковців [3; 6; 13]. В своїх працях вчені акцентують увагу на проблеми трудової міграції, на дисбаланси між попитом і пропозицією робочої сили, що обумовлюють структурно-динамічні зміни на ринку праці, на наслідки пандемії та її вплив на формування принципово нових відносин на сучасному ринку праці, на питання забезпечення зайнятості випускників закладів вищої освіти та молоді у відповідності 3 потребами роботодавців тощо.

Виділення невирішених раніше частин загальної проблеми. В той же час, слід відмітити, що демографрічні, глобалізаційні та інноваційно-технологічні процеси та технології обумовлюють появу нової моделі ринку праці - «Праця 4.0». Як зазначають автори [5], концепція «Праця 4.0» виступає як трудова парадигма, базисом якої є мережево-цифрові технології, що розвиваються в межах Четвертої промислової революції. Для розуміння проблем, які виникають під час фрормування нової моделі ринку праці необхідно проведення постійного динамічного аналізу ситуації в цій сорері. Для прийняття своєчасних й обгрунтованих рішень щодо майбутнього розвитку ринку праці необхідно також враховувати сучасні фрактори та тенденції на ринку праці, які спричинені пандемією «COVID-19».

Формулювання цілей статті (постановка завдання). Метою даної статті є проведення аналізу національного ринку праці, виявлення динамічних і структурних змін на ньому в сучасних умовах фрункціонування економіки.

Виклад основного матеріалу дослідження. На фрормування сучасного ринку праці великий вплив здійснюють існуючі тренди в світовому й національному соціально-еконо- 
мічному та демограсрічному розвитку. Серед них виділяють зниження чисельності населення та підвищення його старіння, зниження долі молоді та частки населення у працездатному віці й потенційної робочої сили (дітей та підлітків) в чисельності населення, зростання навантаження працюючого населення, активізація відтоку робочої сили за кордон, збільшення працюючих пенсіонерів у складі зайнятого населення за секторами економіки, дисбаланс між підготовкою фрахівців у закладах вищої освіти і потребами економіки та роботодавців в них, масове впровадження інфрормаційно-комунікаційних технологій та віртуалізація процесу праці. Крім того, слід зазначити, що формування нового ринку праці в сучасних умовах відбувається під впливом пандемії «COVID-19», що зумовлює аналітиків проводити дослідження й прогнозувати попит і пропозицію робочої сили з урахуванням цього фрактору.

Як вказують дослідження Міжнародної організації праці (МОП) [14], пандемія коронавірусу може спричинити гірші наслідки для ринку праці, ніж фрінансова криза 2008-2009 рр., пандемія «COVID-19» призведе до скорочення 25 млн робочих місць у світі.

Розглянемо ситуацію на ринку праці України в період пандемії та проведемо її порівняння 3 попередніми періодами. На рис. 1 наведено рівень офріційного безробіття населення за місяцами 2019-2021 рр. за даними Державної служби зайнятості України [2].

На рис. 1 наведено інфрормацію щодо офріційно зареєстрованих безробітних в Україні по відношенню до чисельності населення. Враховуючи, що тільки 22\% безробітних звер- таються за послугами до Державної служби зайнятості [1], тобто статус безробітного має лише кожний п'ятий безробітний українець, реальний рівень безробіття може бути значно більшим. Але, навіть за даними офріційного безробіття, бачимо, що безробіття в Україні за січень-лютий 2019-2020 рр. знаходилось майже на однаковому рівні. На початку пандемії (березень 2020 р.) аналітики Держстату та Держзайнятості робили прогноз, що в 2020 році кількість вакансій, зареєстрованих у Державній службі зайнятості, складе 1246 тис. осіб, що буде на 8\% більше, ніж в 2019 році, а рівень зареєстрованого безробіття буде на рівні 14,7\%. [1]. Як видно з рис. 1, дійсно в квітні 2020 року, із введенням жорсткого карантину, відбулося різке підвищення рівня безробіття, яке тривало до закінчення першої хвилі пандемії - серпня-вересня 2020 р. Потім в грудні 2020 року знову почав зростати рівень безробіття, він становив 11\%, що дорівнювало рівню безробіття у квітні. Ситуація 3 початку 2021 року не стабілізувалася, рівень безробіття зростає.

Загалом, з початку карантину в Україні статус безробітного отримали майже 432 тисячі осіб (станом на кінець серпня 2020 р.), що на $67 \%$ більше, ніж за аналогічний період минулого року [2]. Станом на початок березня 2021 року в Україні 610,9 тис. осіб безробітного населення проти 153,6 тис. вакансій [2].

Як показують дослідження [3], пандемія «COVID-19» спричинила на ринок праці такі негативні наслідки, як зниження економічної активності та рівня зайнятості населення через підвищення захворюваності та зниження обсягів пропозиії робочої сили; обмеження мігра-

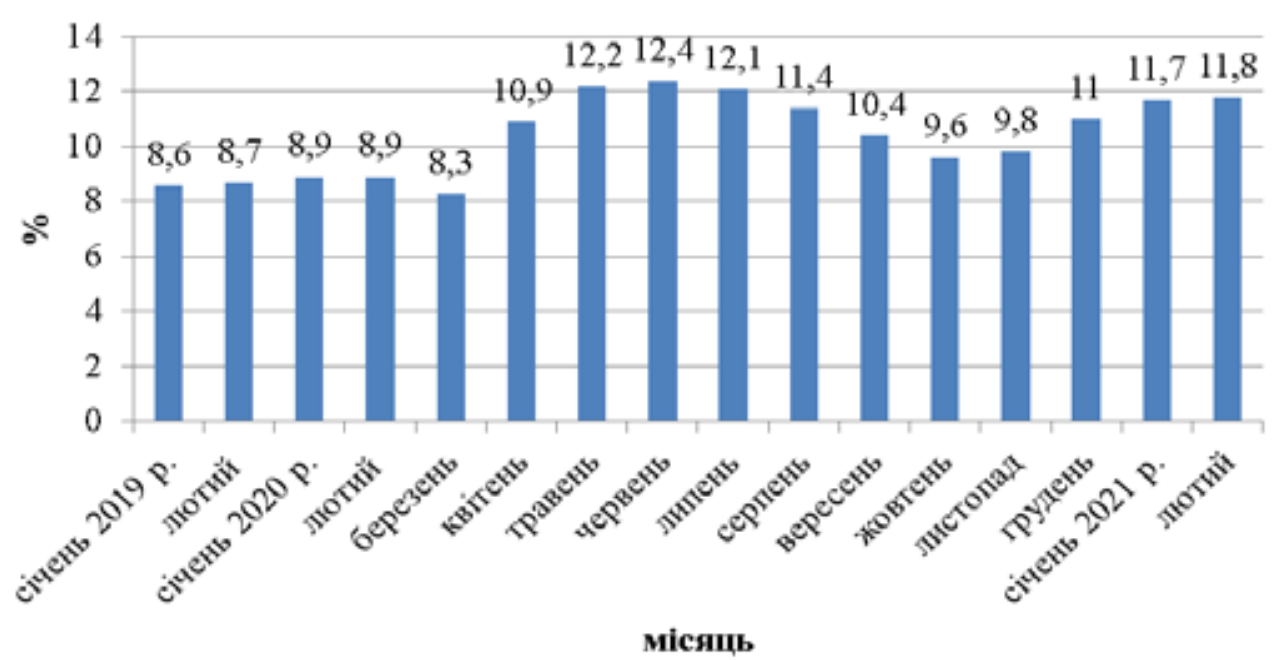

Рис. 1. Рівень безробіття (у \% до чисельності населення) Джерело: авторська розробка за даними [2] 
ційних рухів та затримка інвестиційних процесів, що призвели до зменшення кількості нових робочих місць та зниження доходів населення; поширення неповної та неформальної зайнятості; погіршення стану справ щодо соціального захисту населення та зростання соціальної нерівності в суспільстві. 3 іншого боку, втрата джерел отримання доходів призвела до погіршення ситуації на ринку товарів та послуг, поглибила й загострила проблеми бізнесу, що веде до падіння економіки.

На рис. 2 наведено динамічні зміни кількості зареєстрованих вакансій та кількості претендентів на 1 вакансію за місяцями 2019, 2020 та 2021 рр. [2].

Як видно 3 рис. 2, ситуація 3 вакансіями показує, що їх кількість за січень-лютий 2020 року порівняно з січнем-лютим 2019 року була на однаковому рівні, але в результаті впливу пандемії, вже за аналогічний період 2021 року кількість вакансій знизилась на 34-42\%, кількість офріційно зареєстрованих безробітних за цей період, порівняно з відповідним періодом минулих років, підвисилась майже на 30\%, дефріцит вакансій підвисився майже в 2 рази, а кількість претендентів на 1 вакансію склала 8-9 осіб проти 5 осіб за аналогічний період минулих років.

Дану інорормацію підтверджують і кадрові агентства України - кількість претендентів, які подали свої резюме, зросла на $60 \%$, в той час кількість пропонованих робочих місць продо- вжує знижуватися. При цьому, найсильніший удар припав на малий бізнес - тут 35\% підприємців-роботодавців заявили або про вже закритий бізнес, або про наміри зробити це найближчим часом [9].

Проведений аналіз змін в структурних характеристиках безробіття та зайнятості, показав, що дефіцит вакансій посилився за всіма видами економічної діяльності, відповідно підвищилась кількість претендентів на 1 вакансію. У січні-лютому 2021 року кількість безробітних значно перевищує кількість вакансій в сільському господарстві в 7,6 раза, в переробній промисловості в 2,7 раза, в оптовій та роздрібній торгівлі в 4,5 раза, в сорері орінансів та страхової діяльності - в 11,9 раза, в державному управлінні - в 3,9 раза [2], тобто саме ці види економічної діяльності стали найбільш ураженими в результаті пандемії коронавірусу.

Аналіз масового вивільнення працівників в регіональному розрізі [2] у січні-лютому 2021 року в порівнянні з аналогічним періодом 2020 року свідчить, що збільшення вивільнення працівників спостерігається в Вінницькому регіоні (більше 6,5 тис. осіб), Полтавському, Львівському, Кіровоградському, Дніпропетровському регіонах (на рівні 3,0-3,6 тис. осіб), Луганському, Рівненському, Тернопільському регіонах (більше 2,8 тис. осіб), Миколаївському, Донецькому, Одеському регіонах (на рівні 1,7-2,1 тис. осіб), Волинському та Хмельниць-
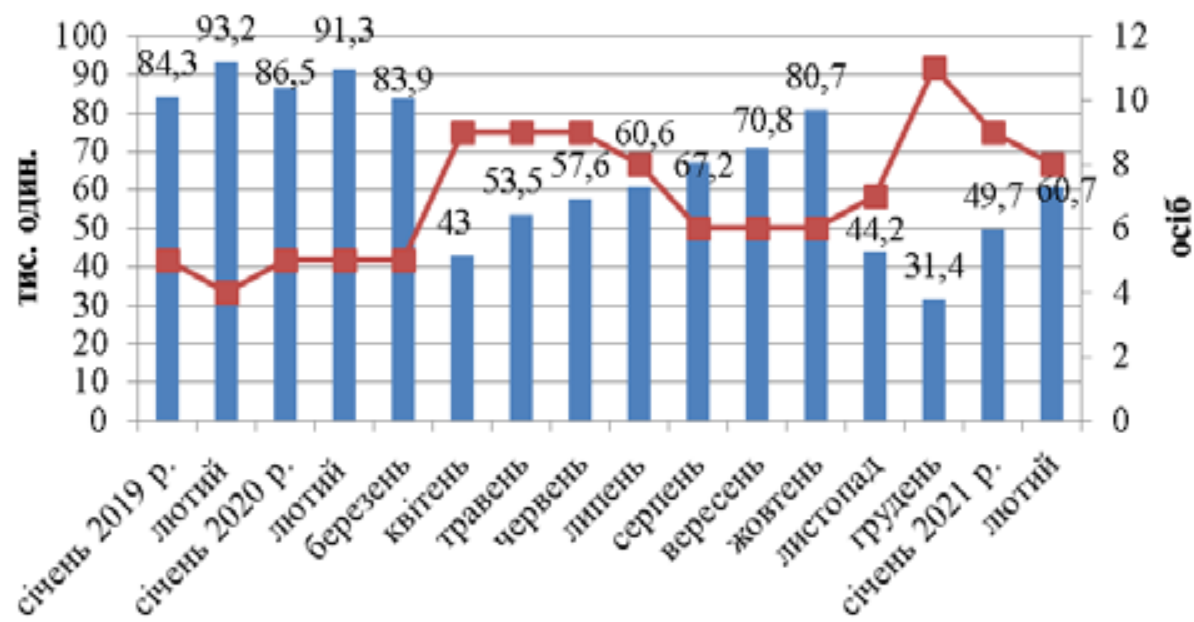

місяць

—. Кіькість зареєстрованих вакансій, тис.

- Кількість претендентів на 1 вакансію, осіб

Рис. 2. Динаміка кількості зареєстрованих вакансій та кількості претендентів на 1 вакансію

Джерело: авторська розробка за даними [2] 
кому регіонах (від 0,8 до 1,3 тис. осіб). В інших регіонах спостерігається зменшення кількості вивільнених працівників: найбільше зменшення в Житомирській, Ченігівській та Харківській областях (від 3,7 до 4,3 тис. осіб), найменше зменшення - в м. Київ (на 0,8 тис. осіб).

Структурний аналіз змін на ринку праці показав, що безробітними в результаті пандемії стали сотні тисяч громадян серед представників як інтелектуальної праці, так і найпростіших профресій.

На рис. 3 наведено кількість зареєстрованих безробітних, кількість вакансій та кількість претендентів на 1 вакансію за професійними групами, станом на 1 березня 2021 р. [2].

Як видно 3 рис. 3, найбільший десріцит вакансій спостерігається за професійною групою службовців та керівників (19 осіб на 1 вакансію) та кваліфрікованих робітників сільського господарства (20 осіб на 1 вакансію). Кількість вакансій порівняно з кількістю безробітних серед цих профресійних груп $€$ найменшою. Якщо порівнювати 3 аналогічним періодом 2020 року, то кількість вакансій знизилась в середньому майже на $37 \%$, а кількість безробітних - підвисилась на 33\%. [2] У період карантину вакансії в основному були в галузі послуг і торгівлі, в сфрері технічного обслуговування устаткування й низькокваліфрікованої роботи.
Проведений аналіз тенденцій щодо структурних змін на ринку праці дозволив виділити найбільш затребувані сфрери, уподобання роботодавців та пошукувачів роботи та провести їх порівняння у 2020 році та у січні 2021 року [7; 10]. У табл. 1 наведено порівняння ключових показників ринку праці за вказані періоди.

За всіма вказаними в табл. 1 профресійними сорерами у 2020 році відбулося підвищення кількості вакансій порівняно з 2019 роком, крім адміністративного персоналу - попит на фрахівців цієї сорери залишився на тому ж рівні. Що стосується пропозиції робочої сили, то підвищення відбулося серед випускників ЗВО та студентства, в сорері продаж та транспорту. Аналіз уподобань щодо досвіду роботи свідчить, що більша частина роботодавців (52\%) потребують фрахівців 3 мінімальним досвідом роботи - від 1 до 3 років, і тільки $3 \%$ хотіли б взяти на роботу відносно досвідчену людину, яка має досвід роботи більше 6 років. Взагалі без досвіду роботи готові взяти 20\% роботодавців. Разом 3 тим ситуація 3 пошукачами роботи є протилежною. У більшості резюме (60\%), розміщених на міжнародному кадровому порталі HeadHunter, вказано, що кандидати мають більше 6 років досвіду, а мінімальний досвід має лише $11 \%$ кандидатів.

Аналіз типів зайнятості показав, що майже всі роботодавці (95\%) шукають фрахівців на повну зайнятість, у той же час 77\% кандида-

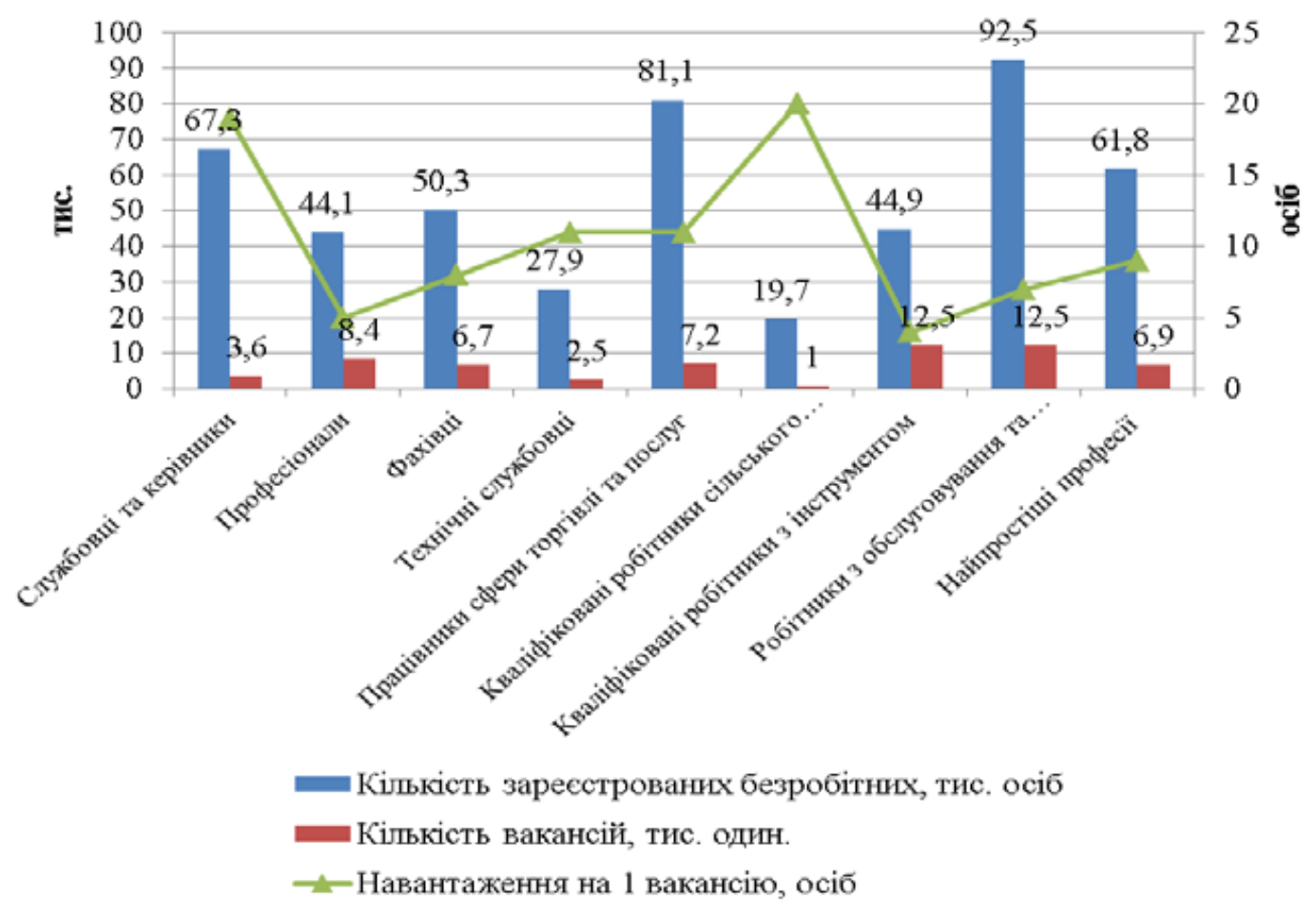

Рис. 3. Ситуація на ринку праці за професійними групами станом на 01.03.2021 p. 
Порівняння ключових показників ринку праці

\begin{tabular}{|c|c|c|c|}
\hline $\begin{array}{c}\text { Tоп-10 профресійних } \\
\text { сфрер за кількістю } \\
\text { вакансій }\end{array}$ & $\begin{array}{c}\text { Toп-10 профресійних } \\
\text { сорер за кількістю } \\
\text { резюме }\end{array}$ & $\begin{array}{c}\text { Очікування } \\
\text { роботодавців } \\
\text { та кандидатів щодо } \\
\text { досвіду роботи }\end{array}$ & \begin{tabular}{|c|} 
Очікування \\
роботодавців \\
та кандидатів щодо \\
типу зайнятості \\
\end{tabular} \\
\hline \multicolumn{4}{|c|}{2020 рік } \\
\hline 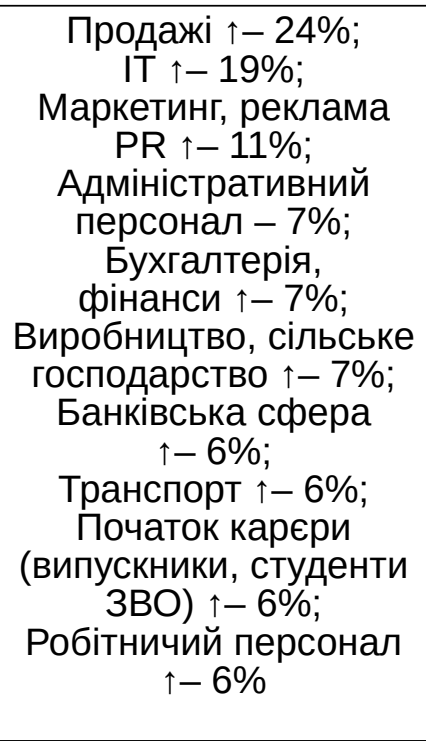 & $\begin{array}{c}\text { Початок карєри } \\
\text { (випускники, студенти } \\
\text { ЗВО) } \uparrow-19 \% ; \\
\text { Продажі } \uparrow-11 \% ; \\
\text { ІТ } \downarrow-9 \% ; \\
\text { Адміністративний } \\
\text { персонал - 8\%; } \\
\text { Бухгалтерія, фрінанси } \\
-6 \% ; \\
\text { Маркетинг, реклама } \\
\text { РR } \downarrow-6 \% ; \\
\text { Транспорт }-5 \% ; \\
\text { Виробництво, } \\
\text { сільське господарство } \\
\downarrow-7 \% ; \\
\text { Вищий менеджмент } \\
\downarrow-4 \% ; \\
\text { Мистецтво, розваги, } \\
\text { мас-медіа } \downarrow-3 \%\end{array}$ & $\begin{array}{c}\text { Очікування } \\
\text { роботодавців: } \\
\text { від 1до } 3 \text { років - 52\%; } \\
\text { від Здо } 6 \text { років - 25\%; } \\
\text { понад } 6 \text { років - 3\%; } \\
\text { без досвіду - } 20 \% \\
\text { Досвід роботи } \\
\text { кандидатів в резюме: } \\
\text { від 1до } 3 \text { років - 11\%; } \\
\text { від Здо } 6 \text { років - 13\%; } \\
\text { понад } 6 \text { років - } 60 \% ; \\
\text { без досвіду - } 16 \%\end{array}$ & $\begin{array}{c}\text { Очікування } \\
\text { роботодавців: } \\
\text { повна зайнятість - } \\
\text { 95\%; } \\
\text { часткова } \\
\text { зайнятість - 4\%; } \\
\text { інші види } \\
\text { зайнятості - 1\% } \\
\text { Уподобання } \\
\text { кандидатів: } \\
\text { повна зайнятість - } \\
77 \% ; \\
\text { часткова зайнятість } \\
-13 \% ; \\
\text { інші види зайнятості } \\
-10 \%\end{array}$ \\
\hline \multicolumn{4}{|c|}{ Січень 2021 року } \\
\hline $\begin{array}{c}\text { Продажі - 28\%; } \\
\text { ІТ - 20\%; } \\
\text { Банківська ссрера - 9\%; } \\
\text { Бухгалтерія, } \\
\text { орінанси - 8\%; } \\
\text { Маркетинг, реклама } \\
\text { РR - 8\%; } \\
\text { Адміністративний } \\
\text { персонал - 8\%; } \\
\text { Початок карєри } \\
\text { (випускники, студенти } \\
\text { ЗВО) - 7\%; } \\
\text { Медицина - 6\%; } \\
\text { Будівництво - 6\%; } \\
\text { Виробництво, сільське } \\
\text { господарство - 6\% }\end{array}$ & $\begin{array}{c}\text { Продажі - 13\%; } \\
\text { Початок карєри } \\
\text { (випускники, студенти } \\
\text { ЗВО) - 10\%; } \\
\text { ІТ - 10\%; } \\
\text { Адміністративний } \\
\text { персонал - 8\%; } \\
\text { Вищий менеджмент } \\
\downarrow-7 \% ; \\
\text { Бухгалтерія, } \\
\text { орінанси - 6\%; } \\
\text { Маркетинг, реклама } \\
\text { РR - 6\%; } \\
\text { Виробництво, } \\
\text { сільське } \\
\text { господарство - 7\%; } \\
\text { Транспорт - 4\%; } \\
\text { Будівництво - 4\% }\end{array}$ & $\begin{array}{c}\text { Очікування } \\
\text { роботодавців: } \\
\text { від 1до } 3 \text { років - 48\%; } \\
\text { від Здо } 6 \text { років - 20\%; } \\
\text { понад } 6 \text { років - 2\%; } \\
\text { без досвіду - 30\% } \\
\text { Досвід роботи } \\
\text { кандидатів в резюме: } \\
\text { від 1до } 3 \text { років - 11\%; } \\
\text { від Здо } 6 \text { років - 15\%; } \\
\text { понад } 6 \text { років - } 60 \% ; \\
\text { без досвіду - } 14 \%\end{array}$ & - \\
\hline
\end{tabular}

Джерело: авторська розробка за даними [7; 10]

тів шукають саме такий тип зайнятості. Лише 13\% претендентів готові мати часткову зайнятість на роботі, однак попит з боку роботодавців на таких фрахівців набагато менший - лише $4 \%$ роботодавців хотіли б найняти кандидата на часткову зайнятість.

Як зазначають експерти порталу HeadHunter [7], більшість пошукачів роботи мають аналітичні, організаційні, комунікативні та автономні компетенності стосовно вміння користування компьютером, презентації результатів розрахунків, командної роботи, ведення переговорів, керування проектами, мають організаторські навички, володіють англійською мовою (до 30\% претендентів).

Якщо подивитись на ситуацію у січні 2021 року, то бачимо, що не відбулося значних змін за ключовими параметрами ринку праці та очікуваннями й уподобаннями роботодавців й потенційних найманих працівників. У той же час, слід відмітити, що претенденти були активнішими, ніж роботодавці - кількість розміщених резюме перевищило вакансії в шість разів, тобто дефріцит вакансій поглибився. Крім того, зявився десріцит кадрів 3 медицини та будівництва. 
Як вважають спеціалісти [7], основним фрактором розвитку ринку праці в 2021 році $€$ продовження кризи, що викликана пандемією «COVID-19» і спостерігатиметься лише повільне відновлення робочих процесів в тих галузях, де це можливо.

Висновки. Пандемія «COVID-19» змінила соціально-економічні та трудові відносини в усьому світі. Карантинні заходи спричинили суттєвий негативний вплив на діяльність усіх, без винятку, бізнес-структур, а отже, й на форомування ринку праці, який забезпечує діяльність суб'єктів господарювання. В цих умовах відбулося падіння доходів населення й зростання тіньового сектору зайнятості та прихованого безробіття.

Для подолання кризових явищ на ринку праці необхідно приймати управлінські рішення як оперативні (під час дії каран- тину), так і стратегічні (протягом декількох років після закінчення карантиних заходів). Для прийняття обгрунтованих управлінських рішень необхідно мати якісні статистичні дані, отримані шляхом проводення постійного моніторингу реального стану соціальнотрудової сорери та з'ясуванні фракторів, які спричиняють певні тенденції й транссрормації в соціально-трудових відносинах.

Головними векторами розвитку, які вплинуть на майбутній ринок праці, стануть процеси діджиталізації та використання цифррових технологій, на підставі яких буде забезпечуватися можливість виконання роботи та навчання у віддаленому доступі. А це, в свою чергу, змінить вектор розвитку усієї національної економіки в напрямку орормування та розвитку ринку праці в новій якості.

\section{СПИСОК ВИКОРИСТАНИХ ДЖЕРЕЛ:}

1.В Минэкономики пояснили рост безработицы в Украине. URL: https://www.rbc.ua/rus/news/minekonomikipoyasnili-rost-bezrabotitsy-1579616163.html (дата звернення: 27.03.2021).

2.Державний центр зайнятості. URL: https://www.dcz.gov.ua/storinka/analityka-ta-statystyka (дата звернення: 30.03.2021).

З.Зуб М.Я., Вергелес І.В. Коронавірус як чинник формування нового ринку праці в регіонах України. URL: https://www.ndifp.com/1579/ (дата звернення: 17.04.2021).

4. Кибанов А.Я. Экономика и социология труда. Москва : ИНФРА-М, 2006. 584 с.

5. Колот А., Герасименко О. Сфера праці в умовах глобальної соціоекономічної реальності 2020: виклики для України. URL: http://library.fes.de/pdf-files/bueros/ukraine/16344.pdf (дата звернення: 30.03.2021).

6. Костриця В.І., Бурлай Т.В. Дисбаланси і дивергенція у сфері зайнятості: підходи ЄС та України до їх подолання. Український соціум. 2020. № 1(72). С. 83-107.

7.Пандемический 2020-й. Итоги года на рынке труда. URL: https://grc.ua/article/28012 (дата звернення: 17.04.2021).

8.Рой В., Жабінець О. Видимі та латентні наслідки COVID-19 для регулювання соціально-трудових відносин в сфрері МСБ України. Київ, 2020. URL: http://eap-csf.org.ua/wp-content/uploads/2020/12/Vidimi-ta-latentninaslidki-COVID-19-.pdf (дата звернення: 05.04.2021).

9.Рынок труда в апреле-2020: безработица стремительно растет, работодатели выжидают. URL: http://sd.net.ua/2020/04/11/rynok-truda-aprel-2020.html (дата звернення: 27.03.2021).

10. Рынок труда - 2021. Что интересного подбросил локдаун в январе. URL: https://grc.ua/article/28092 (дата звернення: 05.04.2021).

11. Солодовник О. О. Заходи забезпечення безпеки банківської системи у звязку із пандемією коронавірусу. Проблеми розвитку фрінансових послуг. Матеріали Всеукраїнської науково-практичної інтернет конференції 19 листопада 2020 р. Частина 1. Харків : Харк. нац. ун-т будів. та архіт., 2020. С. 28-30.

12. Україна у 2020-2021 роках: наслідки пандемії. Департамент стратегічного планування та макроекономічного прогнозування Міністерства розвитку економіки, торгівлі та сільського господарства України. 2020. URL: https://www.me.gov.ua/Documents/Download?id=454cd56e-90c6-467b-9dd2-82f9dad87e0a (дата звернення: 05.04.2021).

13. Український ринок праці: імперативи та можливості змін : колективна монографрія / за ред. І.Л. Петрової, В.В. Близнюк; IEП НАН України. Київ, 2018. 356 c. URL: http://ief.org.ua/docs/mg/306.pdf (дата звернення: 05.04.2021).

14.Як пандемія COVID-19 змінила ринок праці в Україні. URL: https://www.ukrinform.ua/rubric-society/ 3104312-ak-pandemia-covid19-zminila-rinok-praci-v-ukraini.html (дата звернення: 30.03.2021). 


\section{REFERENCES:}

1.V Minjekonomiki pojasnili rost bezraboticy $v$ Ukraine [The Ministry of Economy explained the rise in unemployment in Ukraine]. Available at: https://www.rbc.ua/rus/news/minekonomiki-poyasnili-rost-bezrabotitsy-1579616163.html (accessed 27 March 2021).

2.Derzhavnyj centr zajnjatosti [State Employment Center]. Available at: https://www.dcz.gov.ua/storinka/analityka-ta-statystyka (accessed 30 March 2021).

3.Zub M.Ja., Vergheles I.V. (2020) Koronavirus jak chynnyk formuvannja novogho rynku praci v reghionakh Ukrajiny [Coronavirus as a factor in the formation of a new labor market in the regions of Ukraine]. Available at: https://www.ndifp.com/1579/ (accessed 17 April 2021).

4. Kibanov A.Ja. (2006) Jekonomika i sociologija truda [Economics and Sociology of Labor]. Moskva: INFRA-M, 584 p.

5. Kolot A., Gherasymenko O. (2020) Sfera praci v umovakh ghlobaljnoji socioekonomichnoji realjnosti 2020: vyklyky dlja Ukrajiny [The sphere of work in the conditions of the global socio-economic reality 2020: challenges for Ukraine]. Available at: http://library.fes.de/pdf-files/bueros/ukraine/16344.pdf (accessed 30 March 2021).

6. Kostrycja V.I., Burlaj T.V. (2020) Dysbalansy i dyverghencija u sferi zajnjatosti: pidkhody JeS ta Ukrajiny do jikh podolannja [Employment imbalances and divergence: EU and Ukrainian approaches to overcoming them]. Ukrajinsjkyj socium, no. 1(72), pp. 83-107.

7.Pandemicheskij 2020-j. Itogi goda na rynke truda [Pandemic 2020. Results of the year on the labor market]. Available at: https://grc.ua/article/28012 (accessed 17 April 2021).

8.Roj V., Zhabinecj O. (2020) Vydymi ta latentni naslidky COVID-19 dlja reghuljuvannja socialjno-trudovykh vidnosyn v sferi MSB Ukrajiny [Visible and latent consequences of COVID-19 for the regulation of social and labor relations in the field of SMEs of Ukraine]. Available at: http://eap-csf.org.ua/wp-content/uploads/2020/12/Vidimi-talatentni-naslidki-COVID-19-.pdf (accessed 05 April 2021).

9. Rynok truda v aprele - 2020: bezrabotica stremitel'no rastet, rabotodateli vyzhidajut [Labor market in April 2020: unemployment is growing rapidly, employers are biding their time]. Available at: http://sd.net.ua/2020/04/11/ rynok-truda-aprel-2020.html (accessed 27 March 2021).

10. Rynok truda - 2021. Chto interesnogo podbrosil lokdaun v janvare [Labor market -2021 . What interesting lockdown threw in January]. Available at: https://grc.ua/article/28092 (accessed 05 April 2021).

11. Solodovnyk O.O. (2020) Zakhody zabezpechennja bezpeky bankivsjkoji systemy u zvjazku iz pandemijeju koronavirusu [Measures to ensure the security of the banking system in connection with the coronavirus pandemic]. Problemy rozvytku finansovykh pos/ugh. Materialy Vseukrajinsjkoji naukovo-praktychnoji internet konferenciji 19 lystopada 2020 r. Chastyna 1. Kharkiv: Khark. nac. un-t budiv. ta arkhit., pp. 28-30.

12. Ukrajina u 2020-2021 rokakh: naslidky pandemiji. Departament strateghichnogho planuvannja ta makroekonomichnogho proghnozuvannja Ministerstva rozvytku ekonomiky, torghivli ta siljsjkogho ghospodarstva Ukrajiny [Ukraine in 2020-2021: consequences of the pandemic. Department of Strategic Planning and Macroeconomic Forecasting of the Ministry of Economic Development, Trade and Agriculture of Ukraine]. Available at: https://www.me.gov.ua/Documents/Download?id=454cd56e-90c6-467b-9dd2-82f9dad87e0a (accessed 05 April 2021).

13. Ukrajinsjkyj rynok praci: imperatyvy ta mozhlyvosti zmin (2018) [Ukrainian labor market: imperatives and opportunities for change]: kolektyvna monoghrafija / za red. I.L. Petrovoji, V.V. Blyznjuk; IEP NAN Ukrajiny. Kyiv, 356 p. (in Ukrainian)

14. Jak pandemija COVID-19 zminyla rynok praci v Ukrajini [How the COVID-19 pandemic changed the labor market in Ukraine]. Available at: https://www.ukrinform.ua/rubric-society/3104312-ak-pandemia-covid19-zminilarinok-praci-v-ukraini.html (accessed 30 March 2021). 